Колодійчук Володимир, доктор економічних наук, професор, професор кафедри менеджменту, Львівський національний університет ветеринарної медицини та біотехнологій ім. С.З. Гжицького, м. Львів; ORCID ID 0000-0003-2757-6299 e-mail: V-A-K@ukr.net

https://doi.org/10.29038/2411-4014-2020-03-143-152

\title{
ПРІОРИТЕТИ ЗОВНІШНЬОЕКОНОМІЧНОЇ ДІЯЛЬНОСТІ ПІДПРИЕМСТВ АГРОПРОМИСЛОВОГО КОМПЛЕКСУ ЛЬВІВСЬКОЇ ОБЛАСТІ
}

Досліджено структуру експортно-імпортних операцій агропромислових підприємств Львівської області та дано оцінку її ефективності. Позитивне сальдо зовнішньої торгівлі АПК Львівської області формується за рахунок сировинної структури експорту, яка надаючи підприємствам ситуативні вигоди у можливості швидкого одержання валютних коштів, загалом не відповідає державним інтересам. Переважну більшість найменувань агропромислової продукції область імпортує, незважаючи на сприятливий ресурсний потенціал для іiі виробництва. Для області пріоритетними напрямками міжнародної підтримки є обмін досвідом та залучення інвестиційних ресурсів у сферу виробництва, переробки та зберігання аграрної продукції. Серед експортних пріоритетів зовнішньоекономічної діяльності підприємств АПК є торгівля продукцією переробних підприємств, експорт органічних товарів та використання транзитного потенціалу області.

Ключові слова: зовнішньоекономічна діяльність, сільськогосподарське підприємство, агропромисловий комплекс, експорт, імпорт, зовнішньоторговельне сальдо.

\section{Колодийчук Владимир, доктор экономических наук, професор, профессор кафедры менеджмента, Львовский национальный университет ветеринарной медицины и биотехнологий им. С.3. Гжицького, г. Львов}

\section{ПРИОРИТЕТЫ ВНЕШНЕЭКОНОМИЧЕСКОЙ ДЕЯТЕЛЬНОСТИ ПРЕДПРИЯТИЙ АГРОПРОМЫШЛЕННОГО КОМПЛЕКСА ЛЬВОВСКОЙ ОБЛАСТИ}

Исследована структура экспортно-импортных операций агропромышленных предприятий Львовской области и дана оценка ее эффективности. Положительное сальдо внешней торговли АПК Львовской области формируется за счет сырьевой структуры экспорта, которая предоставляя предприятиям ситуативные выгоды в возможности быстрого получения валютных средств, в общем не соответствует государственным интересам. Подавляющее большинство наименований агропромышленной продукции область импортирует, несмотря на благоприятный ресурсный потенциал для ее производства. Для области приоритетными направлениями международной поддержки является обмен опытом и привлечения инвестиционных ресурсов в сферу производства, переработки и хранения аграрной продукции. Среди экспортных приоритетов внешнеэкономической деятельности предприятий АПК является торговля продукцией перерабатывающих предприятий, экспорт органических товаров и использования транзитного потенциала области.

Ключевые слова: внешнеэкономическая деятельность, сельскохозяйственное предприятие, агропромышленный комплекс, экспорт, импорт, внешнеторговое сальдо.

Kolodiichuk Volodymyr, D.Sc. (Economics), Professor of the Department of Management, Professor Stepan Gzhytskyi National University of Veterinary Medicine and Biotechnologies, 


\section{PRIORITIES OF FOREIGN ECONOMIC ACTIVITY OF ENTERPRISES OF THE AGRO-INDUSTRIAL COMPLEX OF LVIV REGION}

Introduction. The economic development of the region is determined by the resource potential and the ability to use it effectively. Among the branches of the national economy of Ukraine, the most important place is occupied by the agro-industrial complex, which forms not only a powerful export potential of the state, but also is the basis for the development of many branches of the processing industry in the country. This is especially true for Lviv region, where significant capacities for processing agricultural raw materials are concentrated, but the regional structure of foreign economic operations indicates the dominance of raw material exports. The purpose of the article. Determining the priorities of foreign economic activity of agro-industrial enterprises of Lviv region, taking into account the export potential and import needs of goods and services. Results. The positive balance of foreign trade of the agro-industrial complex of Lviv region is formed by the export of grain crops, sugar, fat and oil. At the same time, the vast majority of products are imported by the region, despite the favorable resource potential for its production. Among the priority areas of international support for the agro-industrial complex of the Lviv region, we see the implementation of experience exchange programs for the formation of an institutional environment, improving the level of management and human resources of industry enterprises, and implementing international innovation projects. In addition to organizational support, the region needs real investments in promising agricultural sectors, their infrastructure support and the creation of vertically integrated systems for integrated production and sale of finished products. Among the export priorities of foreign economic activity of agricultural enterprises are trade in products of processing enterprises, export of organic goods and use of transit potential of the region. Conclusions. Determining the priorities of foreign economic activity of the agro-industrial complex of the region will solve the problem of forming an effective structure of foreign economic operations of enterprises, taking into account regional characteristics and national interests.

Key words: foreign economic activity, agricultural enterprise, agro-industrial complex, export, import, foreign trade balance.

Постановка проблеми та їі значення. Збалансований економічний розвиток держави створює передумови для зростання добробуту іï населення та підвищує значимість країни у міжнародному поділі праці. Економічний розвиток держави повинен базуватися на відповідних домінантах, що здатні спричинити системний ефект поступального руху всієї економіки. Обмежені ресурси необхідно спрямовувати у ті галузі, які здатні бути локомотивом для розвитку інших і для умов України пріоритетним напрямком є розвиток аграрного сектора економіки. Розвиток Львівської області, порівняно із центральними та південно-східними областями України, меншою мірою залежить від сільськогосподарського виробництва з огляду на природно-ресурсний потенціал, однак в області сконцентровані значні потужності для переробки сільськогосподарської сировини. Прикордонне розташування області сприяє розвитку зовнішньоекономічних зв'язків 3 країнами Свросоюзу, однак структура цих зв'язків не повною мірою презентує галузевий виробничий потенціал економіки регіону, що спричинює втрати потенційних прибутків. Натомість структура імпорту продуктів харчування часто-густо створює зайву конкуренцію для внутрішніх виробників $\mathrm{i}$ призводить до неефективного витрачання валютних коштів на оплату доданої вартості іноземним товаровиробникам. Отож визначення пріоритетів зовнішньоекономічної діяльності агропромислового комплексу області дозволить вирішити проблему формування ефективної структури зовнішньоекономічних операцій підприємств із врахуванням регіональних особливостей та національних інтересів.

Аналіз останніх досліджень і публікацій. Зовнішньоекономічна діяльність агропромислових підприємств розглядається у наукових публікаціях С. Кваші і Н. Голомші [1], Т. Осташка [2], В. Россохи і О. Шарапи [3], О. Шпичака і О. Боднара [4] та інших авторів. Зокрема, автори В. Россоха i О. Шарапа провели аналіз наслідків для України підписання угоди про зону вільної торгівлі з СС [3, c. 52], визначили завдання розвитку експортного потенціалу сільського господарства [3, с. 58-60], для реалізації яких необхідне удосконалення транспортних тарифів, законодавчого поля та інформаційного середовища зовнішньоекономічної діяльності. Умови забезпечення конкурентоспроможності вітчизняної сільськогосподарської продукції на світовому аграрному ринку досить детально розглянуто у публікації С. Кваші та Н. Голомші [1].

Вчені О. Шпичак і О. Боднар у своєму дослідженні [4, с. 13] акцентують увага на експорті зерна 3 позицій зіставлення його доданої вартості з альтернативними варіантами і прийшли до висновку, 
що визначена сукупна додана вартість при переробці у молоко і м'ясо перевищує показник при експорті непереробленого зерна відповідно у 2,2 і 2,5 рази. Питанням експорту зерна та продуктів його переробки значну увагу також приділяють Г. Черевко та П. Гарасим [5].

У публікації Т. Осташка [2] розглядається експорт агропродовольчої продукції в країни Європейського Союзу в межах і поза межами імпортних тарифних квот з урахуванням місткості імпортного сегмента відповідних продуктових ринків і митних тарифів ЄС. Проте проведені дослідження торкаються загальнодержавних питань міжнародної торгівлі і дещо обмежують зміст зовнішньоекономічної діяльності, акцентуючи увагу переважно на експортних операціях агропромислових підприємств. Авторське бачення зовнішньоекономічних зв'язків полягає у визначенні оптимальної структури експортно-імпортних операцій з метою збалансованого розвитку внутрішнього ринку та забезпечення максимальної прибутковості від експорту агропродовольчих товарів.

Мета і завдання статті. Метою статті $є$ визначення пріоритетів зовнішньоекономічної діяльності агропромислових підприємств Львівської області з огляду на експортний потенціал та потреби імпорту товарів і послуг.

Для досягнення поставленої мети вирішувались наступні завдання: проаналізувати зовнішньоекономічне сальдо Львівської області та дати оцінку його структури; на основі аналізу внутрішнього потенціалу агропромислового комплексу Львівської області сформувати пропозиції щодо оптимізації експортно-імпортних операцій із врахуванням економічних пріоритетів та інтересів внутрішніх товаровиробників.

Викладення основного матеріалу та обгрунтування отриманих результатів дослідження. Глобалізація світової економіки визначає міжнародну спеціалізацію кожної країни, що залежить від потенціалу національної економіки з позицій забезпечення іiї ресурсами. Серед галузей національної економіки України найбільш вагоме місце посідає агропромисловий комплекс, який формує не лише потужний експортний потенціал держави, а й $є$ основою для розвитку багатьох галузей переробної промисловості всередині країни. Це особливо характерно для Львівської області, де відсутні передумови для екстенсивного ведення сільськогосподарського виробництва, проте є потужний потенціал переробних галузей та сприятливі передумови для їхнього розвитку.

Агропромисловий комплекс Львівської області формує п'яту частину валового регіонального продукту і серед регіонів України область займає провідні місця з виробництва картоплі, молока, м'яса, цукрових буряків та овочів. Однак структура зовнішньоекономічних операцій області (табл. 1) свідчить про переважно сировинний характер експорту товарів та імпорту продукції із доданою вартістю. Позитивне сальдо зовнішньої торгівлі АПК Львівської області (+169,2 млн. дол. США) формується за рахунок експорту зернових культур, цукру, овочевих консервів, жирів та олії тваринного або рослинного походження. Загалом зернові культури та різні жири забезпечують основні валютні надходження, а переважну більшість найменувань продукції (див. табл. 1) область імпортує, незважаючи на сприятливий ресурсний потенціал для ії виробництва. Це особливо стосується м'ясо-молочної сировини та продукції іiі переробки. Недостатньо використовується потенціал борошномельних підприємств області, а також харчової індустрії, спиртової промисловості тощо.

На наш погляд, структура зовнішньої торгівлі підприємств АПК області носить ситуативний і нескоординований характер, спричинений неефективною політикою регіональних органів управління. Відсутність чітких орієнтирів регіональної політики щодо зовнішньої торгівлі дезорганізує виробників товарів та спричинює здійснення зовнішньоекономічних операцій, які загалом не відповідають державним інтересам, але дають можливість одержати валютний прибуток для підприємства.

У системі зовнішньої торгівлі координуюча роль регіональних органів влади повинна полягати у визначенні потреб області, які можна задовольнити за рахунок імпорту товарів і послуг, а також визначити структуру пропозиції експортного потенціалу. Причому для підприємств області важливо не лише забезпечити імпорт товарних позицій та послуг, а й залучити інвестиції та одержати відповідний досвід ефективного ведення господарства.

Серед пріоритетних напрямків міжнародної підтримки агропромислового комплексу Львівської області ми вбачаємо наступне (рис. 1): 
1) Реалізація програм обміну досвідом між українськими виробниками і представниками держав та міжнародних корпоративних структур, що мають багатий досвід ринкових перетворень, у наступних напрямках:

$\checkmark$ формування інституційного середовища, зокрема, адаптація правових норм у відповідності до вимог ВТО та ЄС шляхом ініціювання змін до національного законодавства;

Таблиия 1

Товарна структура зовнішньої торгівлі підприємств агропромислового комплексу Львівської області у 2019 році

\begin{tabular}{|c|c|c|c|c|c|c|}
\hline \multirow[b]{2}{*}{$\begin{array}{l}\text { Найменування } \\
\text { товарів }\end{array}$} & \multicolumn{3}{|c|}{ Експорт } & \multicolumn{3}{|c|}{ Імпорт } \\
\hline & $\begin{array}{c}\text { тис. } \\
\text { дол. } \\
\text { США }\end{array}$ & $\begin{array}{l}\text { у \% до } \\
2018\end{array}$ & $\begin{array}{c}\text { у\% до } \\
\text { загаль- } \\
\text { ного } \\
\text { обсягу }\end{array}$ & $\begin{array}{c}\text { тис. } \\
\text { дол. } \\
\text { США }\end{array}$ & $\begin{array}{l}\text { у \% до } \\
2018\end{array}$ & $\begin{array}{c}\text { у\% до } \\
\text { загаль- } \\
\text { ного } \\
\text { обсягу }\end{array}$ \\
\hline Живі тварини & 171,9 & 5,1 & 0,02 & 11610,6 & 112,0 & 2,11 \\
\hline М'ясо та субпродукти & 10561,2 & 108,0 & 1,47 & 35986,9 & 81,6 & 6,55 \\
\hline Риба і ракоподібні & 268,0 & 1485,8 & 0,04 & 30712,3 & 183,2 & 5,59 \\
\hline $\begin{array}{l}\text { Молоко та молочні продукти, яйця } \\
\text { птиці; натуральний мед }\end{array}$ & 2812,4 & 128,1 & 0,39 & 14931,1 & 175,1 & 2,72 \\
\hline $\begin{array}{l}\text { Інші продукти тваринного } \\
\text { походження }\end{array}$ & 5822,4 & 118,9 & 0,81 & 2538,5 & 75,8 & 0,46 \\
\hline $\begin{array}{l}\text { Усього продукти тваринного } \\
\text { походження }\end{array}$ & 19636,0 & 97,0 & 2,73 & 95779,4 & 115,3 & 17,43 \\
\hline Овочі & 2628,7 & 85,6 & 0,37 & 62757,2 & 218,1 & 11,42 \\
\hline Їстівні плоди та горіхи & 16330,6 & 110,2 & 2,27 & 142704,2 & 140,6 & 25,97 \\
\hline Кава, чай & 387,8 & 224,4 & 0,05 & 30301,4 & 119,6 & 5,51 \\
\hline Зернові культури & 214458,2 & 160,4 & 29,84 & 166,6 & 99,3 & 0,03 \\
\hline $\begin{array}{l}\text { Продукція борошномельно- } \\
\text { круп'яної промисловості }\end{array}$ & 127,3 & 261,6 & 0,02 & 807,8 & 145,2 & 0,15 \\
\hline Насіння і плоди олійних рослин & 91900,5 & 129,5 & 12,78 & 3860,2 & 187,7 & 0,70 \\
\hline $\begin{array}{l}\text { Усього продукти рослинного } \\
\text { походження }\end{array}$ & 325833,1 & 146,2 & 45,33 & 240597,4 & 153,5 & 43,78 \\
\hline продукти з м’яса, риби & - & - & - & 4005,1 & 492,6 & 0,73 \\
\hline $\begin{array}{l}\text { цукор і кондитерські вироби } 3 \\
\text { цукру }\end{array}$ & 34862,1 & 61,2 & 4,85 & 3791,6 & 200,3 & 0,69 \\
\hline какао та продукти з нього & 5971,7 & 161,6 & 0,83 & 18334,6 & 154,3 & 3,34 \\
\hline готові продукти із зерна & 15953,2 & 190,6 & 2,22 & 9151,6 & 177,3 & 1,67 \\
\hline продукти переробки овочів & 39906,9 & 190,1 & 5,55 & 8877,5 & 114,4 & 1,62 \\
\hline різні харчові продукти & 15347,3 & 103,4 & 2,14 & 39988,5 & 110,5 & 7,28 \\
\hline $\begin{array}{l}\text { алкогольні і безалкогольні напої та } \\
\text { оцет }\end{array}$ & 8424,1 & 130,6 & 1,17 & 23037,5 & 115,9 & 4,19 \\
\hline $\begin{array}{l}\text { залишки і відходи харчової } \\
\text { промисловості }\end{array}$ & 61464,9 & 129,9 & 8,55 & 39880,5 & 110,2 & 7,25 \\
\hline $\begin{array}{l}\text { тютюн і промислові замінники } \\
\text { тютюну }\end{array}$ & 5171,4 & 109,1 & 0,72 & 58202,7 & 80,5 & 10,59 \\
\hline Усього готові харчові продукти & 187101,6 & 114,5 & 26,03 & 205269,6 & 106,9 & 37,36 \\
\hline $\begin{array}{l}\text { Жири та олії тваринного або } \\
\text { рослинного походження }\end{array}$ & 186211,1 & 155,7 & 25,91 & 7876,8 & 199,2 & 1,43 \\
\hline Усього & 718781,8 & - & 100,0 & 549523,2 & - & 100,0 \\
\hline
\end{tabular}

Джерело: за даними Головного управління статистики у Львівській області (https://www.lv.ukrstat.gov.ua/) 
$\checkmark$ підвищення рівня управлінського і кадрового потенціалу підприємств галузі сільського господарства та переробної сфери шляхом фахового консультування, навчання, стажування спеціалістів за кордоном, проведення циклів тренінгів, курсів, семінарів та вебінарів;

$\checkmark$ реалізація перспективних міжнародних бізнес-проєктів, зокрема, формування міжнародних інноваційних проєктів, наукових та виробничих кластерів;

$\checkmark$ інтеграція наукових та науково-дослідних установ із виробничою сферою, формування замовлень на підготовку спеціалістів під потреби конкретних підприємств, розвиток спільних міжнародних наукових проєктів як в галузі агропромислового виробництва, так й екології сільської місцевості;

$\checkmark$ підтримка діяльності дорадчих служб щодо формування та розвитку кооперативного руху.

Зокрема завдяки допомозі закордонних партнерів досягнуто значних успіхів у розвитку кооперативного руху в області. За підтримки канадсько-українського проєкту «Підвищення конкурентноздатності молочного сектору в Україні та обласної дорадчої служби» у Буському районі успішно функціонує обслуговуючий кооператив «Побужани», який реалізовує молоко та надає послуги з заготівлі кормів.

Збутом молочної продукції також успішно займається сільськогосподарський обслуговуючий кооператив «Покрова», який знаходиться у с. Заболотниці Бродівського району. На Стрийщині діє два сільськогосподарські обслуговуючі кооперативи: «Молочар» та «Лисятицький», які організовують збір і реалізацію молока та надають послуги з заготівлі кормів.

Прикладом успішної кооперації на території Жовківського району $\epsilon$ діяльність сільськогосподарських обслуговуючих кооперативів «Агродвір», «Загора», «Лелик», які заготовляють від населення овочі, картоплю, корми та молоко, а на території Кам'янка-Бузького району - сільськогосподарські кооперативи «Агрослав», «Фортуна», «Добротворець», що надають послуги з заготівлі і реалізації плодоовочевої та молочної продукції.

У Сколівському районі успішно функціонує сільськогосподарський обслуговуючий кооператив «Бескид», який заклав розсадник лікарських трав і виготовляє фасовані трав'яні чаї з дикоросів $\mathrm{i}$ лікарських рослин, що користуються великим попитом серед споживачів, у тому числі й закордонних.

2) Реалізація міжнародних інвестиційних проектів для реорганізації українських аграрних підприємств, інвестування в створення (оновлення) основних засобів, використання та розвиток новітніх виробничих та “зелених" технологій та формування логістичної мережі, зокрема (див. рис. 1):

$\checkmark$ техніко-технологічне забезпечення використання альтернативних джерел енергії;

$\checkmark$ прокладання та ремонт автошляхів як у сільській місцевості, так i у напрямках транспортування сировини і готової продукції до споживача, формування мережі складів аграрної продукції та транспортних хабів;

$\checkmark$ вдосконалення митної інфраструктури Львівської області з метою підвищення пропускної здатності митних терміналів та швидкості митного обслуговування зовнішньоекономічних терміналів [6];

3) Здійснення комплексу допоміжних заходів щодо формування вертикально-інтегрованих агарних комплексів 3 метою створення замкнутого ланцюжка "виробництва-переробки та реалізації продукції” задля зменшення частки трансакційних витрат у собівартості реалізованої продукції та справедливого розподілу валової доданої вартості, таких як (див. рис. 1):

$\checkmark$ виробництво малопоширених, проте перспективних та інвестиційно-привабливих галузей та культур, зокрема, розвиток садівництва, плодоягідного виробництва, овочівництва, вирощування енергетичної верби, мискантусу та виробництво круп;

$\checkmark$ створення умов для тривалого та якісного зберігання сільськогосподарської продукції 3 високими якісно-кількісними характеристиками збереженості, в першу чергу молочної та плодовоовочевої продукції. В комплекс цих заходів входить:

а) забезпечення ферм сучасними доїльними установками;

б) надання технічних засобів для забезпечення збору, пастеризації та транспортування молока;

в) впровадження сучасних технологій зберігання отриманої продукції; 
г) формування резервного та дотаційного фонду для дрібних виробників молока та їх кооперативних об'єднань;

д) будівництво сучасних теплиць;

е) будівництво овоче-, картопле- та зерносховищ;

створення та модернізація потужностей для формування запасів, переробки отриманої сировини та пакування продукції, будівництво реалізаційних мереж та впровадження маркетингових стратегій для просування продукції на ринку аграрної продукції:

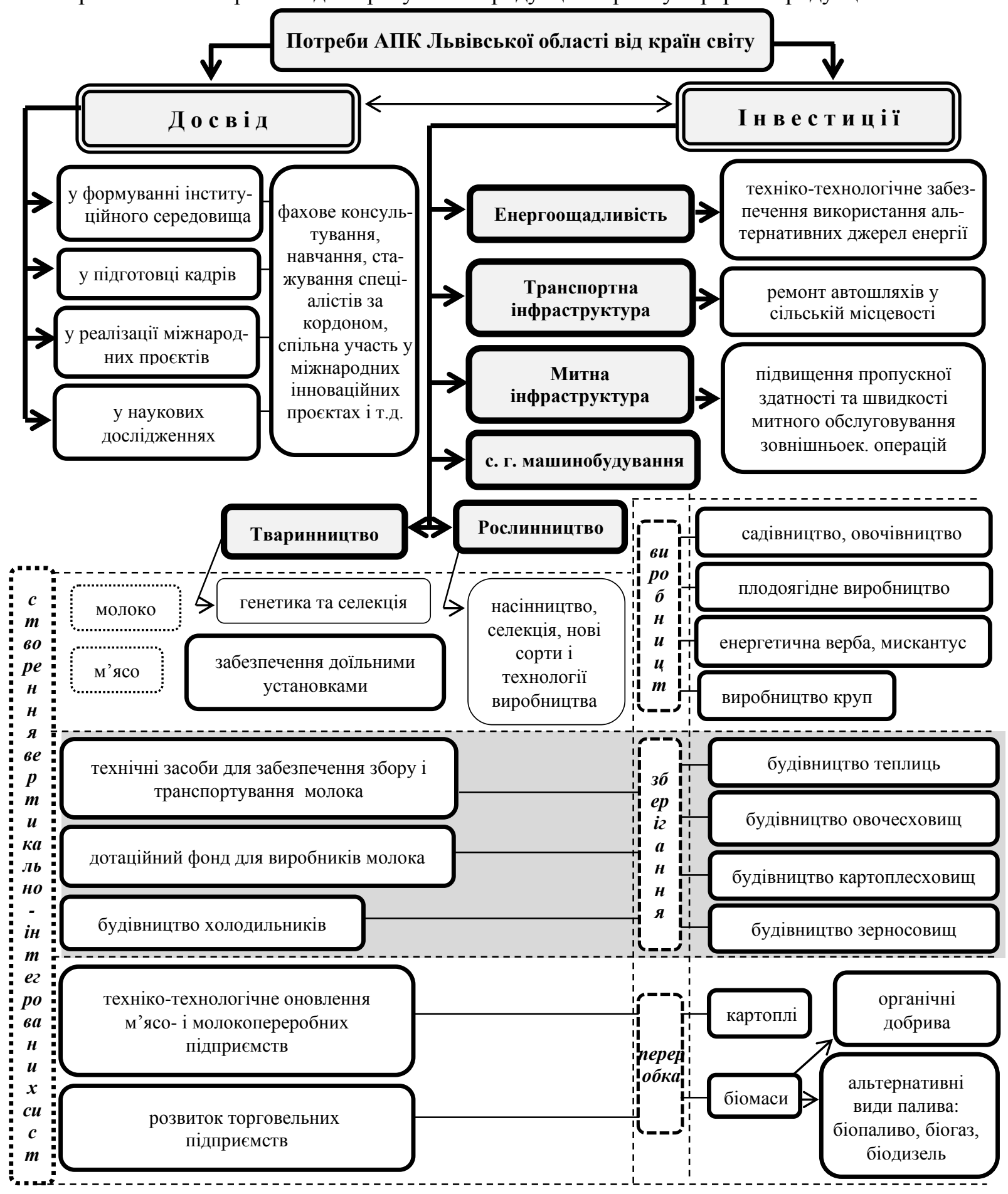

Рис. 1. Пріоритети імпортного потенціалу Львівської області 
а) техніко-технологічне оновлення м'ясо- і молокопереробних підприємств, реконструкцію тваринницьких комплексів, збільшення посівних площ, закладки садів;

б) створення підприємств із переробки біомаси на органічні добрива та альтернативні види палива;

в) формування торгових мереж для реалізації готової продукції.

Головною метою політики держави у сфери зовнішньоекономічної діяльності підприємств сфери АПК Львівської області є формування оптимального балансу зовнішньоторговельних операцій за рахунок нарощування обсягів експорту високотехнологічної продукції, науково-технічних розробок, робіт і послуг та активного пошуку нових ринків збуту, нарощування обсягів конкурентоспроможної експорто-орієнтованої продукції, вивчення та застосування світового досвіду для підвищення конкурентоспроможності економіки регіону. У ході виконання цієї мети серед основних напрямків експорту продукції АПК області варто відмітити (рис. 2):

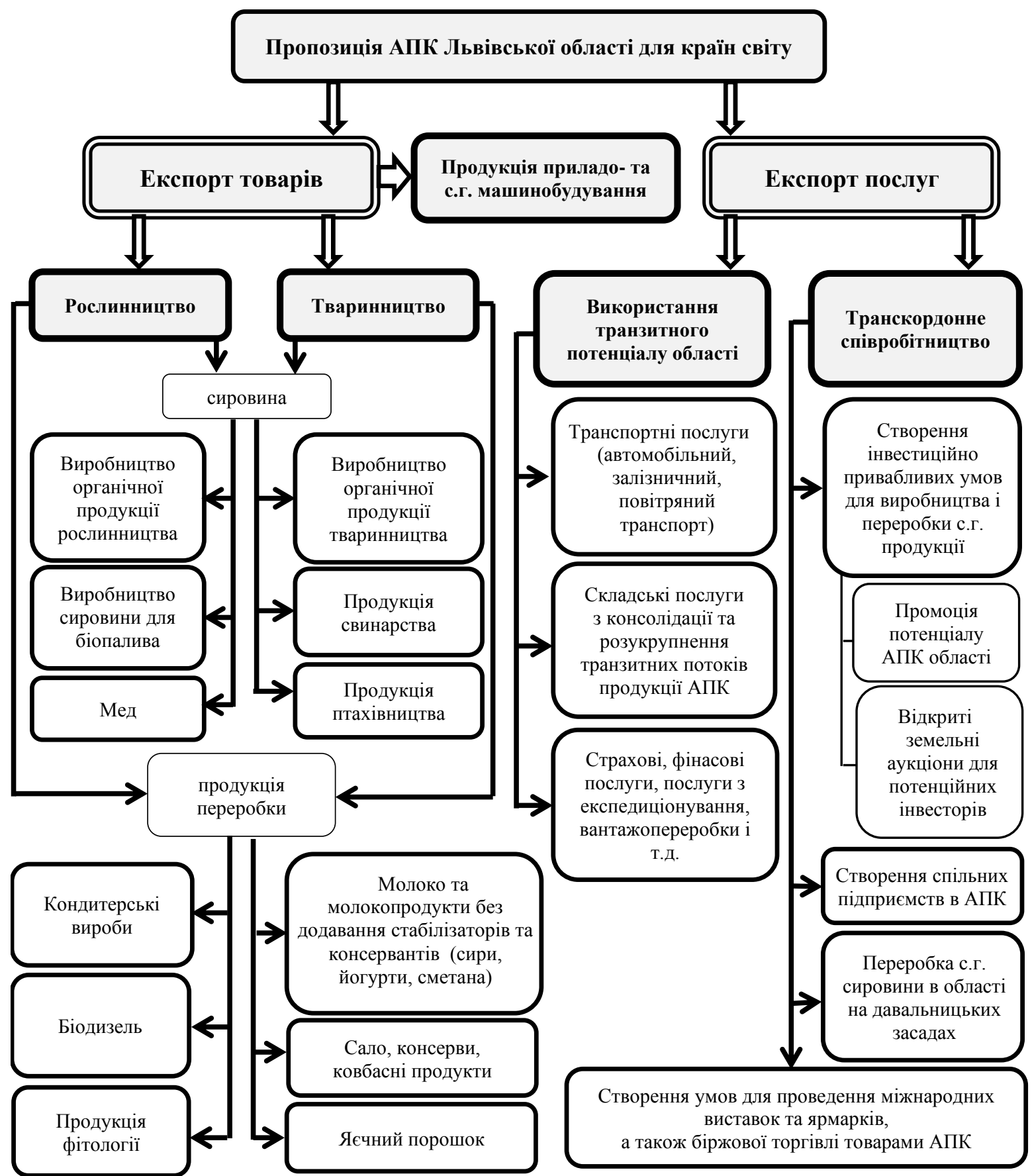

Рис. 2. Пропозиичія підприємств регіонального АПК для країн світу 
1) Експорт агропромислових товарів;

2) Експорт послуг підприємств області.

Експорт агропромислових товарів $\epsilon$ основним напрямом валютних надходжень області. Протягом 2019 року обсяг експорту сільськогосподарської продукції та продуктів харчування Львівської області зріс і склав 718,8 млн дол. США. Відбулося поступове збільшення обсягів експорту рослинницької продукції та продуктів ï переробки підприємствами Львівщини.

Характерною тенденцією останнього часу є зростання зацікавленості закордонних партнерів в екологічно чистій та органічній продукції і на задоволення цього попиту почали орієнтувати свою діяльність багато українських виробників органічної продукції, зокрема, виробники меду, продукції свинарства та птахівництва тощо. Важливим завданням у цьому напрямку для вітчизняних агропідприємств є забезпечення сертифікації органічної продукції [3, с. 55-56].

Протягом останніх років все більшу частку у загальній вартості експортованих сільськогосподарських товарів займає продукція переробної промисловості, зокрема, варто виділити виробництво вже популярних за кордоном яєчного порошку та кондитерських виробів, а також молоко- та м'ясопродуктів, продукції фітології та біодизель.

Львівська область має вигідне географічне положення, оскільки через їі територію проходять три трансєвропейські логістичні маршрути, область володіє найбільшими в Західному регіоні України земельними, людськими ресурсами та науковим потенціалом.

Використання вигідного географічного положення області дає змогу активно здійснювати підприємницьку діяльність у сфері послуг, зокрема:

$\checkmark$ надання транспортних послуг державними i приватними компаніями у сферах автомобільного, залізничного та повітряного транспорту [7];

$\checkmark$ створення логістичної інфраструктури [8] і формування логістичних хабів та надання складських послуг з консолідації та розукрупнення транзитних потоків продукції АПК [9];

$\checkmark$ створення сервісних компаній з надання страхових та фінансових послуг, а також послуг 3 експедиціонування вантажів та їхньої подальшої вантажопереробки [10].

Поза тим, створення на прикордонних територіях сприятливих умов для економічного співробітництва дасть потужний поштовх для співпраці Львівської області та сусідніх держав щодо створення інвестиційно привабливих умов для виробництва і переробки сільськогосподарської продукції.

Для цього необхідно здійснити:

$\checkmark$ інформаційну підтримку підприємств-експортерів Львівщини щодо розширення їхньої присутності на міжнародних торговельних ринках та пошуку бізнес-партнерів за кордоном [5];

$\checkmark$ вивчення та прогнозування кон'юнктури ринків сусідніх держав;

$\checkmark$ промоцію товарів і послуг, виробниками яких є підприємства сфери АПК області, на зовнішньому ринку, в т.ч. через залучення торговельно-економічних відділів при Посольствах України за кордоном, представлення їх на регіональних, національних та міжнародних виставках, економічних форумах; використання Інтернет-каналів та медіа-ресурсів тощо;

$\checkmark$ створення спільних підприємств в АПК;

$\checkmark$ переробка сільськогосподарської сировини на давальницьких засадах, що передбачає завантаження переробних потужностей області сировиною із сусідніх країн. Привабливості цьому надає дешевше ресурсне забезпечення виробництва в Україні;

$\checkmark$ створення умов для проведення міжнародних виставок та ярмарків, а також біржової торгівлі товарами АПК. Зокрема, найкращим майданчиком у Львові може слугувати найбільший у Західному регіоні України гуртовий ринок “Шувар”, котрий протягом останніх років вносить значний вклад у розвиток транскордонної торгівлі агропромисловою продукцією.

Висновки і перспективи подальших досліджень. Незважаючи на позитивне сальдо зовнішньої торгівлі підприємств агропромислового комплексу Львівської області, відсутність скоординованої регіональної політики щодо міжнародної торгівлі спричинила неефективну структуру зовнішньоекономічних операцій, яка, надаючи підприємствам ситуативні вигоди у можливості одержання валютних коштів, загалом не відповідає державним інтересам. Переважну більшість найменувань агропромислової продукції область імпортує, незважаючи на сприятливий ресурсний потенціал для іï виробництва. Це особливо стосується м'ясо-молочної сировини та продукції іiі 
переробки. Недостатньо використовується потенціал борошномельних підприємств області, а також харчової індустрії, спиртової промисловості тощо.

Серед пріоритетних напрямків міжнародної підтримки агропромислового комплексу Львівської області вбачаємо реалізацію програм обміну досвідом щодо формування інституційного середовища, підвищення рівня управлінського та кадрового потенціалу галузевих підприємств, реалізації міжнародних інноваційних проєктів і спільних наукових досліджень. Крім організаційної підтримки область потребує реальних інвестицій у перспективні галузі АПК, їх інфраструктурне забезпечення та створення вертикально-інтегрованих систем комплексного виробництва і реалізації готової продукції.

Пріоритетними напрямками експортного потенціалу підприємств агропромислового комплексу Львівської області $\epsilon$ експорт агропромислових товарів та послуг. Перевагу у товарній структурі експорту слід надавати продукції переробних підприємств, яких $є$ достатньо в області, а також органічній продукції, попит на яку у світі є дуже високим. Передумовами для експорту послуг $є$ високий транзитний потенціал області та географічні переваги для розвитку транскордонного співробітництва з Європейським Союзом. Розробка дієвих механізмів щодо експорту послуг вимагає подальших досліджень з огляду на відповідність вітчизняного законодавства європейським вимогам.

\section{Джерела та література}

1. Кваша С.М., Голомша Н.С. Конкурентоспроможність вітчизняної сільськогосподарської продукції на світовому аграрному ринку. Економіка АПК. - 2006. - № 5. - С. 99-104.

2. Осташко Т. О. Експорт агропродовольчих товарів у СС: перспективи і завдання. Економіка i прогнозування. - 2016. - № 1. - С. 83-93.

3. Россоха В., Шарапа О. Експортний потенціал аграрних підприємств. Зовнішня торгівля: економіка, фінанси, право. 2016. №4. С. 44-46.

4. Шпичак О. М., Боднар О. В. Вигоди та проблеми експорту зерна з України. Економіка АПК. - 2013. № 10. - C. 5-15.

5. Черевко Г.В., Гарасим П. М. та інші. .Економіка зернопродуктового підкомплексу АПК: [монографія]. Львів: Українські технології, 2000. - 198 с.

6. Колодійчук В. А. Логістична інфраструктура експортного зернового потенціалу України. Агросвіт. 2013. - № 15. - C. 11-16.

7. Kravtsiv V. Kolodiichuk V., Kolodiichuk I. Greening of transport and logistics systems of regional agricultural markets. Economic Annals-XXI: Journal. - 2018. - №171(5-6)'. - P. 38-43.

8. Перебийніс В. І., Перебийніс О. В. Транспортно-логістичні системи підприємств: формування та функціонування: [монографія] / В. І. Перебийніс, - Полтава: РВВ ПУСКУ, 2005. - 207 с.

9. Величко О.П. Логістика в системі менеджменту підприємств аграрного сектору економіки: Монографія. - Дніпропетровськ: Акцент ПП, 2015. - 525 с.

10. Колодийчук В.А., Колодийчук И.А., Погорецкий М.О. Инфраструктурное обеспечение логистики экспорта украинского зерна. Новый университет. - 2013. - № 11 (33). - С. 4-8.

\section{References}

1. Kvasha S.M., Golomsha N.Ye. (2006). Konkurentospromozhnist` vitchyznyanoyi sil`s`kogospodars`koyi produkciyi na svitovomu agrarnomu rynku. [Competitiveness of domestic agricultural products on the world agricultural market]. Ekonomika APK. № 5, 99-104. [in Ukrainian].

2. Ostashko T. O. (2016). Eksport agroprodovol'chy`x tovariv u YeS: perspektyvy i zavdannya. [Exports of agrifood products to the EU: prospects and challenges]. Ekonomika i prognozuvannya. № 1, 83-93. [in Ukrainian].

3. Rossoxa V., Sharapa O. (2016). Eksportny`j potencial agrarny`x pidpryemstv. [Export potential of agricultural enterprises]. Zovnishnya torgivlya: ekonomika, finansy, pravo. № 4, 44-46. [in Ukrainian].

4. Shpychak O. M., Bodnar O. V. (2013). Vygody ta problemy eksportu zerna z Ukrayiny. [Benefits and problems of grain export from Ukraine]. Ekonomika APK. №10, 5-15. [in Ukrainian].

5. Cherevko G.V., Garasym P. M. ta inshi. (2000) Ekonomika zernoproduktovogo pidkompleksu APK: monografiya. [Economics of grain subcomplex of agro-industrial complex: Monograph] Lviv: Ukrayins'ki texnologiyi. [in Ukrainian].

6. Kolodijchuk V. A. (2013) Logistychna infrastruktura eksportnogo zernovogo potencialu Ukrayiny. [Logistics infrastructure of Ukraine's export grain potential]. Agrosvit. № 15, 11-16. [in Ukrainian]. 
7. Kravtsiv V. Kolodiichuk V., Kolodiichuk I. (2018) Greening of transport and logistics systems of regional agricultural markets. Economic Annals-XXI: Journal. №171(5-6)’. 38-43. [in English].

8. Perebyinis, V., \& Perebyinis, O. (2005). Transportno-logistychni systemy pidpryemstv: formuvannya ta funkcionuvannya: monografiya [Transport and logistics systems of enterprises: establishment and performance: monograph]. Poltava: RVV PUSKU. [in Ukrainian].

9. Velychko, O. (2015). Logistyka v systemi menedzhmentu pidpryemstv agrarnogo sektoru ekonomiky: Monografiya [Logistics in the management system of enterprises of the agrarian sector of the economy: Monograph]. Dnipropetrovsk: Akcent PP. [in Ukrainian].

10. Kolodiichuk V.A., Kolodiichuk I.A., Pogoreczkyj M.O. (2013) Infrastrukturnoe obespechenye logystyky eksporta ukraynskogo zerna. [Infrastructure support of Ukrainian grain export logistics] Novyj unyversytet. № 11 (33), 4-8. [in Russian].

Стаття надійшла до редакції 20.08.2020 p. 